\title{
Environment Friendly Minimum Quantity Lubrication Technique
}

\author{
Roshan Lal Virdi \\ Department of Mechanical Engineering, Punjabi University, Punjab, India \\ E-Mail: virdirl@gmail.com
}

\begin{abstract}
Lubricants are always important for the machining of materials for any industry. Large quantity of rational lubricants poses environment and health problems to the workers. Research is focused nowadays on to replace traditional fluids which are harmful to meet the striker laws of environment. Nanofluids can be the alternative if made with proper base oils to protect the environment and workers health. Nanofluids has the ability to transfer more heat with good lubrication effects. Environment friendly nanoparticles with vegetable oils as base fluid in Minimum Quantity Lubrication (MQL) technique can help the industries to eliminate traditional oils.

Keywords: Environment Friendly, Minimum Quantity Lubrication, Technique
\end{abstract}

\section{INTRODUCTION}

A lot of heat is generated to machine hard material. To control the temperature of the cutting zone lot of emulsion based cutting fluids is used which are costly and also damaged the environment when discarded. Not only have these fluids harmed the environment but cause serious problems to the health of workers related to respiratory, dermatology etc. Present attentions are to omit the emulsion based cutting fluids and meet the industry requirements of machining as per environment laws (Silva, 2013, Zhang et al., 2012, F. Klocke, 1997).

\section{LITERATURE REVIEW}

Dry Machining is one of the alternative but for very hard materials lot of heat generated at the cutting zone cause thermal damages to the surface of the material. Minimum Quantity Lubrication (MQL) machining can be an alternative to the problem. MQL is a technique in which small amount of fluid $(60-150 \mathrm{ml} / \mathrm{hr})$ is used for lubrication with compressed air which serves the purpose of cooling. High cost of the coolants and strict environment laws forced the researchers to choose this technique(Tawakoli et al., 2011, Zhang et al., 2015).

Dhar et al. (2006) used this technique and concluded that it can develop better results than flood cooling. Many other researchers also satisfied with the cooling and lubrication of MQL technique which makes him focus of research in the last decade(F. Klocke, 1997, Silva et al., 2005).

Shen et al. (2008) concluded that nanofluid based MQL system is much better in terms of $G$ Ratio, surface roughness and prevent the burning of workpiece. At this stage of research a new coolants were developed by adding solid particles in based fluids to make them more effective in terms of machining parameters. Nanofluids are new fluids made from adding nanoparticles of the size 1-100 nm into traditional coolants(Choi, 1995). Many researchers concluded that heat transfer properties of the nanofluids enhances whic makes them more important in industry where heat exchange devices were used at large scale(Eastman et al., 2001, Yu et al., 2007, Choi et al., 2011).

Radice and Mischler (2006) used alumina based nanofluids and found out that friction reduces by adding $10 \%$ volume of alumina nanoparticles to the acetate buffer solution. Setti et al. (2015) also concluded with reduction in forces and wear rate with allumina based nanofluids. Nanofluids curbs various environment problems but still more challenges are there as rational fluids are harmful.

Khan et al. (2009) used Vegetable oil-based cutting fluids in turning of AISI 9300 and cncluded that tool wear reduces and enhances tool life. Adopting as base fluids in MQL researchers focused on vegetable oils.

Emami et al. (2014) used four types of fluids mineral, hydrocracked, synthetic, and vegetable oils and concluded that vegetable oils can reduce the environmental hazards and also meets the machining criteria.Belluco and De Chiffre (2004) evaluated commercial mineral-based oil and five vegetable-based cutting fluids in the drilling of $316 \mathrm{~L}$ steel and concluded better results with vegetable oils.

Zhang et al. (2015) evaluated grinding different vegetable oils with $\mathrm{MoS}_{2}$ based nanofluid and concluded palm oil due to high viscosity produced best lubrication. Rahim and Sasahara (2011) used vegetable and synthetic ester as base fluid in grinding and concluded vegetable based oil were better lubricants and can replace synthetic ester. et al. Lawal et al. (2014) utilized the Taguchi method to evaluate vegetable and mineral oil cutting fluids in turning AISI 4340 steel with coated carbide tools.

Both palm oil-and cottonseed oil-based cutting fluids have better heat conductivity and environment-friendly properties and that they are better alternatives for machining AISI 4340 steel with coated carbide.Silva (2013) grinded AISI4340 steel with vegetable based MQL system and concluded that it was better than conventional cooling. 


\section{CONCLUSION}

A number of studies in the past on vegetable oils based drilling, turning, grinding etc proved that vegetable oil based MQL not only fulfil the good lubrication effects but also environment friendly technique. This is due the properties of the vegetable oils that can replace traditional fluids. Nanofluids based on vegetable oils meet the required tribological and lubrication properties which proves them better lubricants than pure oil and traditional coolants. $\mathrm{Al}_{2} \mathrm{O}_{3}$ based nanofluids are environment friendly fluids that can replace the traditional coolants in grinding.

\section{REFERENCES}

[1] W. Belluco, and L. De Chiffre, "Performance evaluation of vegetable-based oils in drilling austenitic stainless steel", Journal of Materials Processing Technology, Vol. 148, pp. 171-176, 2004.

[2] C. Choi, M. Jung, Y. Choi, J. Lee, and J. Oh, "Tribological properties of lubricating oil-based nanofluids with metal/carbon nanoparticles", J Nanosci Nanotechnol, Vol. 11, pp. 368-71, 2011.

[3] S. U. S. Choi, "Enhancing Thermal Conductivity of Fluids with Nano Particles, Developments and Applications of Non-Newtonian Flows", FED, Vol. 231, pp. 99-105, 1995.

[4] N. R. Dhar, M. Kamruzzaman, and M. Ahmed, "Effect of minimum quantity lubrication (MQL) on tool wear and surface roughness in turning AISI-4340 steel", Journal of Materials Processing Technology, Vol. 172, pp. 299-304, 2006.

[5] J. A. Eastman, S. U. S. S. Choi, Li, W. Yu, and L. J. Thompson, "Anomalously increased effective thermal conductivities of ethylene glycol-based nanofluids containing copper nanoparticles", Applied Physics Letters, Vol. 78, pp. 718, 2001.

[6] M. Emami, M. H. Sadeghi, A. A. D. Sarhan, and F. Hasani, "Investigating the Minimum Quantity Lubrication in grinding of A12O3 engineering ceramic", Journal of Cleaner Production, Vol. 66, pp. 632-643, 2014.

[7] F. G. E. Klocke, "Dry cutting", CIRP, Vol. 46, No. 2, pp. 519-526, 1997.

[8] M. M. A. Khan, M. A. H. Mithu, and N. R. Dhar, "Effects of minimum quantity lubrication on turning AISI 9310 alloy steel using vegetable oil-based cutting fluid", Journal of Materials Processing Technology, Vol. 209, 5573-5583, 2009.
[9] S. A. Lawal, I. A. Choudhury, and Y. Nukman, "Evaluation of vegetable and mineral oil-in-water emulsion cutting fluids in turning AISI 4340 steel with coated carbide tools", Journal of Cleaner Production, Vol. 66, 610-618, 2014.

[10] S. Radice, and S. Mischler, "Effect of electrochemical and mechanical parameters on the lubrication behaviour of $\mathrm{Al} 2 \mathrm{O} 3$ nanoparticles in aqueous suspensions", Wear, Vol. 261, pp. 10321041, 2006.

[11] E. A. Rahim, and H. Sasahara, "A study of the effect of palm oil as MQL lubricant on high speed drilling of titanium alloys", Tribology International, Vol. 44, pp. 309-317, 2011.

[12] D. Setti, M. K. Sinha, S. Ghosh, and P. Venkateswara Rao, "Performance evaluation of Ti-6Al-4V grinding using chip formation and coefficient of friction under the influence of nanofluids", International Journal of Machine Tools and Manufacture, Vol. 88, pp. 237-248, 2015.

[13] B. Shen, A. J. Shih, and S. C. Tung, "Application of Nanofluids in Minimum Quantity Lubrication Grinding", Tribology Transactions, Vol. 51, pp. 730-737, 2008.

[14] L. R. Silva, "Environmentally friendly manufacturing: behavior analysis of minimum quantity of lubricant - MQL in grinding process", Journal of cleaner production, 2013.

[15] L. R. Silva, E. C. Bianchi, R. E. Catai, R. Y. Fusse, T. V. França, and P. R. Aguiar, "Study on the behavior of the minimum quantity lubricant - MQL technique under different lubricating and cooling conditions when grinding ABNT 4340 steel", Journal of the Brazilian Society of Mechanical Sciences and Engineering, Vol. 27, pp. 192$199,2005$.

[16] T. Tawakoli, M. Hadad, M. H. Sadeghi, A. Daneshi, and B. Sadeghi, "Minimum quantity lubrication in grinding: effects of abrasive and coolant-lubricant types", Journal of Cleaner Production, Vol. 19, pp. 2088-2099, 2011.

[17] W. Yu, D. M. France, S. U. S. Choi, J. L. Routbort, and E. Systems, "Review and assessment of nanofluid technology for transportation and other applications", 2007.

[18] S. Zhang, J. F. Li, and Y. W. Wang, "Tool life and cutting forces in end milling Inconel 718 under dry and minimum quantity cooling lubrication cutting conditions", Journal of Cleaner Production, Vol. 32, pp. 81-87, 2012.

[19] Y. Zhang, C. Li, D. Jia, D. Zhang, and X. Zhang, "Experimental evaluation of MoS2 nanoparticles in jet MQL grinding with different types of vegetable oil as base oil", Journal of Cleaner Production, Vol. 87, pp. 930-940, 2015. 